\title{
A Discounted Cash Flow and Capital Budgeting Analysis of Silvopastoral Systems in the Amazonas Region of Peru
}

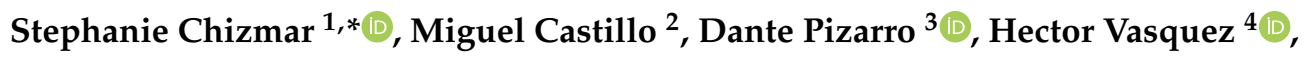

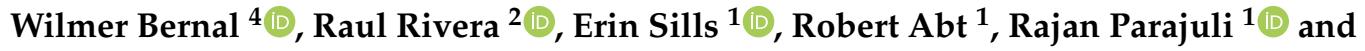 \\ Frederick Cubbage ${ }^{1}$ \\ 1 Forestry and Environmental Resources, North Carolina State University, 2800 Faucette Dr., Raleigh, \\ NC 27695, USA; sills@ncsu.edu (E.S.); bobabt@ncsu.edu (R.A.); rparaju@ncsu.edu (R.P.); \\ cubbage@ncsu.edu (F.C.) \\ 2 Crop and Soil Sciences, North Carolina State University, 101 Derieux Pl, Raleigh, NC 27695, USA; \\ mscastil@ncsu.edu (M.C.); rrivera4@ncsu.edu (R.R.) \\ 3 Animal Science Faculty, Universidad Nacional Agraria La Molina, Lima 15024, Peru; \\ dpizarro@lamolina.edu.pe \\ 4 Facultad de Ingeniería Zootecnista, Agronegocios y Biotecnología, Universidad Nacional Toribio Rodriguez \\ de Mendoza de Amazonas, Chachapoyas 01001, Peru; hvasquez@untrm.edu.pe (H.V.); \\ wilmer.bernal@untrm.edu.pe (W.B.) \\ * Correspondence: sjchizma@ncsu.edu
}

Received: 28 August 2020; Accepted: 24 September 2020; Published: 25 September 2020

check for updates

\begin{abstract}
Silvopasture is a type of agroforestry that could deliver ecosystem services and support local livelihoods by integrating trees into pasture-based livestock systems. This study modeled the financial returns from silvopastures, planted forests, and conventional cattle-pasture systems in Amazonas, Peru using capital budgeting techniques. Forests had a lower land expectation value (USD 845 per hectare) than conventional cattle systems (USD 1275 per hectare) at a $4 \%$ discount rate. "Typical" model silvopastures, based on prior landowner surveys in the Amazonas region, were most competitive at low discount rates. The four actual silvopastoral systems we visited and examined had higher returns (4\%: USD 1588 to USD 9524 per hectare) than either alternative pure crop or tree system, more than likely through strategies for generating value-added such as on-site retail stands. Silvopasture also offers animal health and environmental benefits, and could receive governmental or market payments to encourage these practices.
\end{abstract}

Keywords: silvopasture; economics; financial analysis; carbon payment; Peru

\section{Introduction}

Expanding forest cover remains a global priority to combating trends in deforestation and global climate change. Countries in Latin America, where the livestock sector generates $58-70 \%$ of overall agricultural emissions, are particularly interested in mitigating climate change through integrating forest cover into agricultural production systems [1]. Agroforestry operations combine forest or horticultural species and pasture or cropland to make mixed land-use systems that produce commercial benefits to landowners [2]. Silvopasture, a branch of agroforestry, is a strategic and managed agroecosystem in which livestock, forage, and trees or shrubs are integrated to help improve individual components [3,4]. Silvopastoral systems (SPS) diversify earnings to landowners by generating products on various harvest schedules, from daily as in the case of milk and cheese to multi-year for forest products such as fuelwood, posts, and boards [5]. 
As such, silvopasture has been identified as a key integrated landscape approach that could potentially increase returns to landowners by generating timber and non-timber products, while also improving conditions for forage production and cattle [6]. This most likely occurs when the components of the system have complementary relationships such that tree and cattle-forage production are mutually beneficial, which has been found true at low tree densities in the USA [7]. However, this may not be the case in the absence of established markets and technical knowledge networks. In other words, without access to knowledge and markets, silvopastoral practices may not achieve the social and environmental benefits they have been documented to produce [8].

Recently, the Peruvian government defined its Nationally Determined Contributions, which contemplate reducing 30\% of the greenhouse gas emissions projected for the year 2030 . The government recommended considering strategies such as the recovery of degraded soils with SPS in the Peruvian Amazon. Incorporating SPS in the Peruvian Amazon has the potential to mitigate 1344 metric tons of $\mathrm{CO}_{2} \mathrm{e}$ through intervention on 102,000 hectares [9]. Peru also committed to restore 3.2 million hectares as part of the Bonn Challenge's mission to restore 150 million hectares of the world's degraded and deforested lands by 2020 [10]. Silvopasture is one strategy aimed at increasing forest cover in agricultural systems, augmenting a region's carbon sequestration potential, especially in deforested and degraded ecosystems [1].

Amazonas, a jurisdiction of Northeastern Peru, has an economically disadvantaged rural population that depends on agriculture and animal husbandry as primary income sources. Poverty rates exceed $50 \%$ and malnutrition levels are $30 \%$ or more in parts of Amazonas [11], suggesting a need for governmental intervention aimed at improving the livelihoods of the lower income populace. The rural population of Amazonas, encompassing over half of the total population [12], has opportunities to improve the welfare of landowners, farmers, and associated laborers. Rural landowners, both onsite and absentee, may generate additional income flows from timber and non-timber products by incorporating trees into their agricultural systems. Rural households may also become eligible for payments for ecosystem services through helping to expand tree cover and thereby provide habitat, sequester carbon, or provide other benefits.

The main goal of this paper is to evaluate the financial returns of Peruvian production systems, including silvopasture, typical cattle-pasture operations, and planted tree monocultures, through the application of discounted cash flow and capital budgeting analyses. The main hypothesis of SPS states that mixed-use systems can diversify farm income, reduce biophysical and financial risks, and perhaps, increase total farm returns by providing timber and non-timber products in addition to forage for livestock production. We postulated that the degree of tree and forage competition determines the profitability of SPS. In other words, at a modest tree density, trees may complement forage systems; however, at high tree densities, the production of forage will decline due to competition for resources, especially light. The collaborative team determined productivity data as well as prices of inputs and outputs as reported by local silvopasture practitioners and industry experts to model whole-system cash flows. Finally, we assessed the potential impact of incentive payments on a range of actual and typical landowner income for both absentee and onsite landowners. The rest of this paper is structured in the following five sections: (i) a review of the literature on silvopasture, particularly in tropical and subtropical regions; (ii) the methods we utilized to determine cash flows for multiple land-use systems; (iii) the results of the discounted cash flow and capital budgeting analyses; (iv) a discussion on the profitability of different land-uses; and (v) concluding remarks.

\section{Literature Review}

Loker [13] modeled low-input agroforests to determine their suitability as alternative, sustainable production systems for small-to-medium farmers in the Amazon Basin, as landowners in the region are attracted to cattle management for its multiple economic benefits. Landowners in Uruguay recognized that shelter from silvopasture benefits cattle, fostering increased calving rates [14]. In Argentina, small-scale farmers perceived cash flow diversification through the sale of livestock and forest products 
as the main advantage of silvopasture [15]. Silvopastures also likely provide better microenvironments, reducing climatic-induced stress, such that grazing animals are "happier" and gain weight at a faster rate than when grazing in traditional open pastures [3]. For many species of livestock, deviations in core body temperature more than 2 to $3{ }^{\circ} \mathrm{C}$ negatively impact performance, productivity, and fertility, potentially leading to decreased successful pregnancies [16]. Faster and increased weight gain from improved microenvironments as well as augmented crop growth may lead to higher profits for landowners, as well as better animal welfare in Amazonas.

Agroforests potentially sequester more carbon than pastures or field crops growing under similar ecological conditions [17]. Oliva et al. [18] measured 337.2 tons of carbon stored in Pinus patula silvopastures with 8- to 10-year-old trees in Amazonas. Dube et al. [19] reported that silvopastures in Patagonia, Chile, as well as in Minas Gerais, Brazil [20] required less time than a plantation monoculture to reach similar carbon gains above and below ground. The researchers attributed gains in carbon to the positive interactions between cattle, tree, and pasture components, including increased tree growth. Cubbage et al. [21] reviewed global SPS in eight regions, including areas in Argentina, Uruguay, Chile, and Brazil, and reported that silvopasture is financially competitive with alternative land-use systems and offers biophysical and financial diversity and resilience, attributes critical with the increased occurrences of extreme weather events due to climate change.

Payments for ecosystem (environmental) services (PES) compensate landowners for managing their property to sequester carbon, protect biodiversity, or provide watershed services. Some scientists have argued that in tropical systems the greatest potential for carbon sequestration is through the establishment of tree-based systems on degraded pastures [22]. Programs that provide incentives for forest management on degraded productive lands and supply additional sources of revenue may aid profitability as well as conservation of land-use systems in Amazonas. Orefice et al. [23] found that silvopastures in the U.S. North were financially superior to open pasture or thinned forests. Bruck et al. [24] observed that SPS are less financially profitable than pasture in the southern and western U.S. The study, however, did not account for any animal welfare or joint output effects.

Silvopastures can also shift forage production for livestock and soil quality, resulting in an expanded grazing season and livestock diets higher in protein $[3,23]$. Livestock provides essential elements such as nitrogen, phosphorus, and potassium through nutrient cycling to fertilize forages and trees, which may reduce dependence on additional external inputs $[25,26]$. Pent and Fike [25] suggested there is a complementary biophysical relationship between forage production for livestock and trees, assuming a modest tree density. Silvopastoral systems with relatively low tree densities required reduced weeding, provided increased available nitrogen, improved the microclimate, reduced erosion control costs, and fostered better animal health such as increased pregnancy success rates [26].

\section{Methods}

The Molinopampa district, located in the northeastern section of the Chachapoyas Province, in the southern portion of the Amazonas Region, has an oceanic climate (dry forest lower montane tropical according to Holdridge's Life Zone) [27]. Approximately 75\% of the population in Molinopampa make a living in agriculture, ranching, hunting, and silviculture [28]. The Huayabamba Valley, in the Rodríguez de Mendoza Province, is characterized as having a tropical savanna and warm-humid climate (moisture forest premontane tropical according to Holdridge's Life Zone) [27]. Past surveys of the study area [28-31] found that $61 \%$ and $43 \%$ of the silvopasture producers in the Molinopampa district and the Huayabamba Valley, respectively, own farms that are on less than 10 hectares (ha). Conversely, 10-ha to 30-ha (30-ha+) farms represented $28 \%$ and $42 \%(11 \%$ and $16 \%)$ of the surveyed systems in the Molinopampa district and the Huayabamba Valley, respectively. The field sites for this study, which participated in the past surveys, are located on privately-owned farms, are managed as part of cooperatives with multiple institutions, and range from 10-ha to 65-ha in size [28-31]. Therefore, our sample farms are among the larger size class ownerships for these similar regions, but still within a representative range. 
Universidad Nacional Agraria La Molina (UNALM), El Porvenir Research Station (INIA), the Universidad Nacional Toribio Rodríguez de Mendoza de Amazonas (UNTRM), and North Carolina State University (NCSU) have been collaborating with private landowners over the past five years to better understand the dynamics of applied agroforestry systems [28]. In July 2017, the collaborative team interviewed three landowners and one land manager well-known locally for practicing silvopasture and who have established relationships with the local university UNTRM. We selected these farms since they have established connections to the researchers and are most likely local leaders in their farm practices. Analyzing examples of successful programs may help to illuminate cost-effective characteristics and strategies that could be adapted throughout Amazonas. Cash flow estimations based on the four landowner responses, as well as average costs and benefits from discussions among co-authors, were predicted for each site in addition to "typical" model systems representing average farms in the region documented in the previously mentioned surveys [28-31].

The study collaborators gathered production function data for the case studies and typical model systems, organized in a database, to estimate values from soils, crops, and grazing. We estimated the associated economic impacts of inputs and outputs over a 25-year time horizon, both to calculate Net Present Value and Land Expectation Value. We then performed analyses in Microsoft Excel for Microsoft 365 using discounted cash flows associated with SPS, conventional grazing, and planted forests. The spreadsheets included necessary measures of productivity, product prices and costs, and management schedules, among other site-specific information, to calculate the net returns of annual activities. The operations were modeled as whole land-use regimes due to their complexity and the available information.

Tools in capital budgeting analysis such as Net Present Value (NPV), Land Expectation Value (LEV), Annual Equivalent Income (AEI), and Benefit-Cost Ratio (BCR) allow for comparison of land-use systems. Real discount rates of $4 \%, 8 \%$, and $12 \%$ were used in all financial formulas to represent a range of the opportunity cost of the next best investment. Discount rates account for the future value of income that would equate to income earned in the present through representing preferences for incurring costs and benefits now or in the future, i.e., they capture the opportunity cost of the investment. Since discount rates are often unknown to landowners, most analyses use the internal rate of return of the next best option for comparisons, such as a bank investment [32]. The Internal Rate of Return (IRR) was not relevant and inapplicable for this analysis for ongoing farms since annual benefits always exceeded costs. We excluded land values from NPV and LEV calculations. As such, each metric represents use-values, or income-based values, of the land. We then compared these metrics to the alternative values, market prices for land in the region, to facilitate a discussion on the financial competitiveness of different land-use systems.

$N P V$ measures the amount of capital that an investment returns at a given discount rate through summing the total expenditures and subtracting them from total income [33]. Formula (1) demonstrates how NPVs are calculated in terms of farm and forest costs and revenues.

$$
N P V=\sum_{i=0}^{t} \frac{(B-C)}{(1+i)^{t}}
$$

where $B$ and $C$ represent the annual total benefits and costs, respectively, of the land-use system, $i$ signifies the interest or discount rate, and $t$ is the year of the cash flow.

Similar to NPV, LEV utilizes expenditures, income, and a discount rate to measure the expected cash flow of a land-use in perpetuity. LEV has four assumptions to be viable: (1) identical costs and revenues in all rotations; (2) land-use will be maintained in perpetuity; (3) land requires identical regeneration costs at the beginning of each rotation; (4) the land value does not enter the calculation. In other words, landowners must replicate the following activities, including identical costs of inputs, prices of outputs, and cash flow schedules, into the future: purchase inputs, produce goods and services, extract products, and use or sell products. LEV allows researchers to compare systems of 
different rotation ages as well as how much an investor is willing to pay for the land at a given discount rate by assuming land-use will be continued indefinitely [26]. Formula (2) describes the method of estimating a production system's periodic and perpetual net returns in the present value [34].

$$
\begin{gathered}
L E V=N P V+\frac{N P V}{(1+i)^{T}-1} \\
\text { Or } L E V=\frac{V_{n}}{\left[(1+i)^{n}-1\right]}
\end{gathered}
$$

where NPV equates to the net present value of the system, $T$ is the final year of the system's rotation, $V_{n}$ equates to the net future value of the system at $n$ number of years per period, and $i$ again signifies the interest or discount rate.

AEI expresses NPV or LEV in annual payments equally distributed over the life of the investment (Formula (3)). AEI allows comparison of long-term timber investments with seasonal returns from agriculture by expressing the income of each alternative in annual payments [32].

$$
A E I=L E V * i
$$

where $L E V$ represents the system's land expectation value and $i$ signifies the interest or discount rate.

$\mathrm{BCR}$ relates the total discounted benefits to the total discounted costs. The relation describes present value benefits and costs as a unitless proportion rather than as a difference such as in the case of NPV. The proportion (Formula (4)) reveals the return landowners receive per dollar invested [26].

$$
B C R=\frac{\sum_{i=0}^{t} B_{p}}{\sum_{i=0}^{t} C_{p}}
$$

where $B_{p}$ and $C_{p}$ represent the benefits or revenues and costs or expenditures, respectively, in present value terms.

For price transformations of Peruvian wood products, the co-authors converted from Nuevo Sol per product to USD per cubic meter of wood product. Derived residual stumpage prices, equating to $50 \%$ of the roadside value, were calculated to account for logging and transportation when not given labor amounts for transport and/or sale. As a result, the income generated by the primary landowner as well as additional laborers is captured. For this reason, primary landowner labor was not included in the analysis. In other words, the determined income includes earned income from self-employment of the primary landowner. However, for farms with more than 15 heads of cattle, average annual income data were used to proportionately increase income to outside laborers, additional landowners, and/or land managers, bore as a cost in the modeled scenarios. The average annual income of a farm laborer in Amazonas at the time of the study was USD 11,111.11 [28-31]. The most common land-uses in Amazonas, Peru are dual-production systems of cattle and dairy and cultivation of horticultural and forest products such as coffee, guava, citrus fruits, eucalyptus, and cedar [29,30]. Agroforestry systems in Amazonas are increasingly incorporating multi-strata systems and improved fallows $[29,35,36]$. The study collaborators represented this trend through the selection of field sites of various production complexity.

\section{Results}

Table 1 summarizes the operations based on actual farms and survey observations. The first three rows review typical model systems defined by our project cooperators and previously completed surveys [28-31]. The last four rows describe systems observed in field visits. Both typical and actual farms included a variety of predominantly exotic cattle breeds including Brown Swiss and Holstein and planted non-native Eucalypts and pines. 
Table 1. Description of evaluated scenarios in Amazonas, Peru.

\begin{tabular}{|c|c|c|c|c|c|}
\hline Scenario & $\begin{array}{l}\text { Management } \\
\text { Intensity * }\end{array}$ & Tree Species & $\begin{array}{c}\text { Tree Growth } \\
\left(\mathrm{m}^{3} \mathrm{ha}^{-1} \text { year }^{-1}\right)\end{array}$ & Cattle Breeds & $\begin{array}{l}\text { Number of Cattle } \\
\text { (Lactating Cows) }\end{array}$ \\
\hline \multicolumn{6}{|c|}{ Typical Model Systems (based on prior surveys) } \\
\hline $\begin{array}{l}\text { 10-ha Planted } \\
\text { Forest Only }\end{array}$ & Low & Pinus patula & 5 & - & $\begin{array}{c}0 \\
(0)\end{array}$ \\
\hline $\begin{array}{c}\text { 10-ha } \\
\text { Cattle-Pasture } \\
\text { Only }\end{array}$ & Medium & - & 0 & $\begin{array}{l}\text { Brown Swiss, } \\
\text { Simmental, } \\
\text { Holstein }\end{array}$ & $\begin{array}{l}16 \\
(5)\end{array}$ \\
\hline 10-ha SPS & Medium & $\begin{array}{c}\text { Alnus acuminata, } \\
\text { Eucalyptus globulus, } \\
\text { P. patula }\end{array}$ & 5 & $\begin{array}{l}\text { Brown Swiss, } \\
\text { Simmental, } \\
\text { Holstein }\end{array}$ & $\begin{array}{l}16 \\
(5)\end{array}$ \\
\hline \multicolumn{6}{|c|}{ Actual Systems (field sites) } \\
\hline $\begin{array}{l}\text { 10-ha Cattle + } \\
\text { Trees + Fruit }\end{array}$ & Medium & E. globulus & 5 & Holstein & $\begin{array}{l}21 \\
(6)\end{array}$ \\
\hline $\begin{array}{l}\text { 25-ha Cattle + } \\
\text { Trees + Fruit + } \\
\quad \text { Store }\end{array}$ & High & $\begin{array}{c}\text { P. patula, Cupressus } \\
\text { macrocarpa, E. } \\
\text { globulus, } A . \\
\text { acuminate }\end{array}$ & 5 & $\begin{array}{l}\text { Holstein, } \\
\text { Simmental, } \\
\text { Brown Swiss }\end{array}$ & $\begin{array}{l}38 \\
(8)\end{array}$ \\
\hline $\begin{array}{c}\text { 30-ha Cattle + } \\
\text { Trees }\end{array}$ & High & $\begin{array}{c}\text { E. globulus, A. } \\
\text { acuminate, P. patula }\end{array}$ & 5 & Brown Swiss & $\begin{array}{c}49 \\
(24)\end{array}$ \\
\hline $\begin{array}{l}\text { 65-ha Cattle + } \\
\text { Trees + } \\
\text { Restaurant }\end{array}$ & Medium & $\begin{array}{l}\text { P. patula, C. } \\
\text { macrocarpa }\end{array}$ & 5 & Brown Swiss & $\begin{array}{c}38 \\
(11)\end{array}$ \\
\hline
\end{tabular}

${ }^{*}$ In terms of inputs including labor.

The income from the typical and actual SPS predominately comes from the production of agricultural and horticultural products. Table 2 separately identifies the present value income (at a $4 \%$ discount rate) from wood products as well as agricultural and horticultural products for the one SPS scenario based on the past surveys and the four actual systems. Table 3 displays the capital budgeting results for the typical and actual regimes. Returns for the modeled systems varied from positive to negative net profits depending on management choices, local markets, and the discount rate.

Table 2. Total present value income by product type (discounted at $4 \%$ ).

\begin{tabular}{|c|c|c|c|c|}
\hline \multirow{3}{*}{$\begin{array}{c}\text { SPS Scenario } \\
\text { Typical SPS }\end{array}$} & \multicolumn{4}{|c|}{ Total Income at $4 \%$} \\
\hline & \multicolumn{2}{|c|}{ Wood Products } & \multicolumn{2}{|c|}{ Ag. and Hort. Products } \\
\hline & USD & 3369 & USD & 148,060 \\
\hline 10-ha C + T + F & USD & 2616 & USD & 322,077 \\
\hline 25-ha $C+T+F+S$ & USD & 4657 & USD & 715,614 \\
\hline 30-ha C + T & USD & 2616 & USD & 217,352 \\
\hline 65-ha $C+T+S$ & USD & 2322 & USD & 67,951 \\
\hline
\end{tabular}

C-Cattle; T-Trees; F-Fruit; S-Store (25-ha farm) or Restaurant (65-ha farm).

Table 3. Net present values (NPV) and land expectation values (LEV) of the evaluated scenarios.

\begin{tabular}{ccccccc}
\hline \multirow{2}{*}{ Scenario } & \multicolumn{3}{c}{ NPV (USD/ha) } & \multicolumn{3}{c}{ LEV (USD/ha) } \\
\cline { 2 - 7 } & $\mathbf{4} \%$ & $\mathbf{8} \%$ & $\mathbf{1 2} \%$ & $\mathbf{4} \%$ & $\mathbf{8} \%$ & $\mathbf{1 2} \%$ \\
\hline Typical Forest & 527.87 & -210.61 & -583.94 & 844.74 & -246.62 & -620.44 \\
Typical Cattle-Pasture & 796.88 & 318.64 & 69.53 & 1275.25 & 373.12 & 73.87 \\
Typical SPS & 992.52 & 321.91 & 2.52 & 1588.33 & 376.96 & 2.68 \\
10-ha C + T + F & 5794.18 & 4045.62 & 3040.01 & 9272.43 & 4737.36 & 3230.01 \\
25-ha C + T + F + S & 3626.78 & 1433.91 & 276.45 & 5803.93 & 1679.08 & 293.73 \\
30-ha C + T & 5951.49 & 1840.67 & -261.03 & 9524.17 & 2155.39 & -277.35 \\
65-ha C + T + S & 4603.27 & 2615.55 & 1555.65 & 7366.60 & 3062.77 & 1652.88 \\
\hline
\end{tabular}


For the three regimes modeled based on prior farm owner surveys [28-31], pure timber investments provided the lowest returns to landowners (LEV: $4 \%=$ USD 844.74; $8 \%=-$ USD 246.62; $12 \%=-$ USD 620.44 per ha). Dual-purpose cattle grazing systems earned about 50\% more than the returns of plantation forests at the lowest discount rate (LEV: $4 \%=$ USD 1275.25; $8 \%=$ USD 373.12; $12 \%=$ USD 73.87 per ha). The "typical" silvopasture scenario based on survey findings generated the highest landowner profitability of the hypothetical regimes (LEV: $4 \%=$ USD 1588.33; $8 \%=$ USD 376.96; $12 \%=$ USD 2.68 per ha). At a 12\% discount rate, however, the wait for timber income was penalized more. Consequently, the ranking of systems in respect to landowner profitability changed, signaling conventional cattle-forage regimes to earn more net income than conventional SPS.

The four actual agroforestry systems that we surveyed in Amazonas provided landowners high returns. Again, it is worth noting that these farms were selected by the project co-investigators, and probably are local leaders in their farm practices. The 10-ha farm including planted trees for fruit and timber production and cattle grazing earned relatively high net returns (LEV: 4\% = USD 9272.43; $8 \%=$ USD $4737.36 ; 12 \%=$ USD 3230.01 per ha). The second smallest farm visited, a 25-ha system with planted timber and fruit trees, cattle grazing, and a store on-site for sale of final products, provided acceptable, positive returns at low discount rates (LEV: $4 \%=$ USD 5803.93; $8 \%=$ USD $1679.08 ; 12 \%$ = USD 293.73 per ha). The second largest agroforest, a management-intensive 30-ha cattle grazing regime with a "living-fence" of planted trees, generated positive returns at low discount rates but failed to return positive earnings at a $12 \%$ discount rate (LEV $4 \%=$ USD 9524.17; $8 \%=$ USD $2155.39 ; 12 \%=-$ USD 277.35 per ha). The largest property analyzed, a 65 -ha farm with multiple cattle grazing paddocks and tree plantations, produced acceptable incomes at all discount rates (LEV: $4 \%$ = USD 7366.60; $8 \%$ = USD 3062.77; $12 \%$ = USD 1652.88 per ha).

Figure 1 demonstrates the AEI of the conventional and monoculture regimes. At $4 \%$, the values of all typical systems in Peru ranged from USD 33.79 to USD 51.01/ha/year. Forest monocultures experienced negative returns at higher discount rates. Figure 2 shows the AEI values for mixed land-use regimes. Typical silvopastures experienced positive annual returns at all discount rates. The calculated annual net revenue of actual systems ranged between USD 134.33 and USD 378.99/ha/year at 8\%. The AEI may be multiplied by the number of acres to estimate the system's annual income, including earned income for the self-employed primary landowner. Only the two largest actual operations, the 30-ha (4\% discount rate) and 65-ha systems (all discount rates), earned more than the average annual income for farmers in Amazonas when accounting for total net system returns. Thus, the two larger systems were the only scenarios that support sustainable livelihoods for the landowner(s).

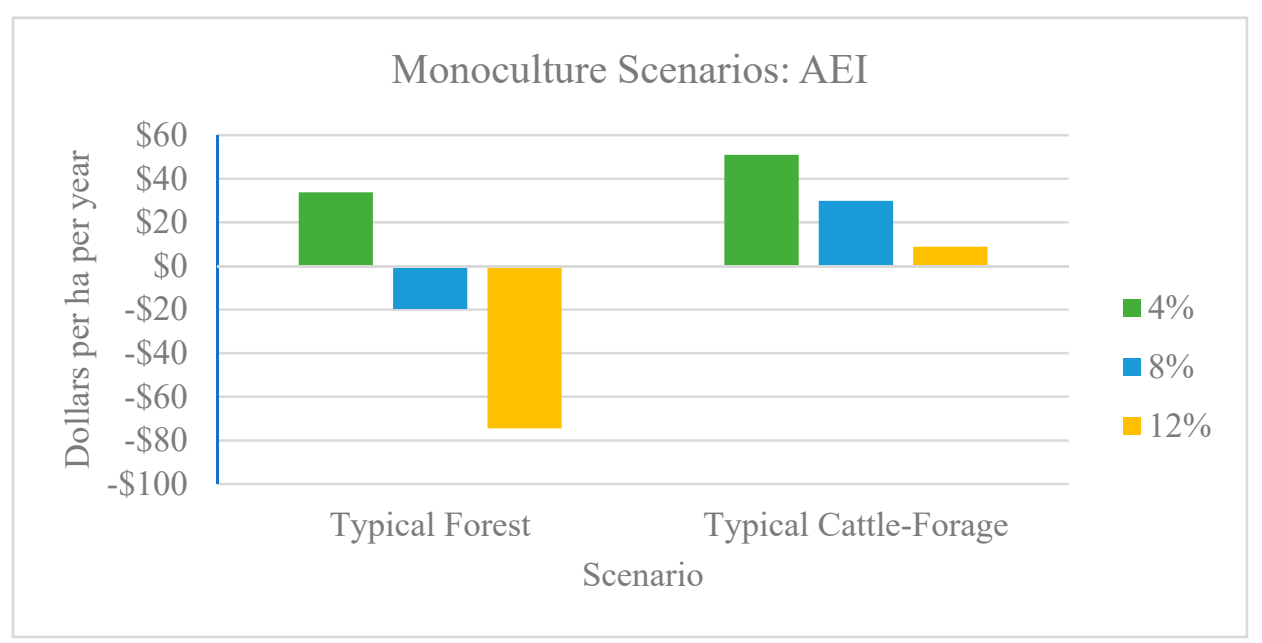

Figure 1. Annual equivalent income (AEI) of traditional forest and cattle systems. 


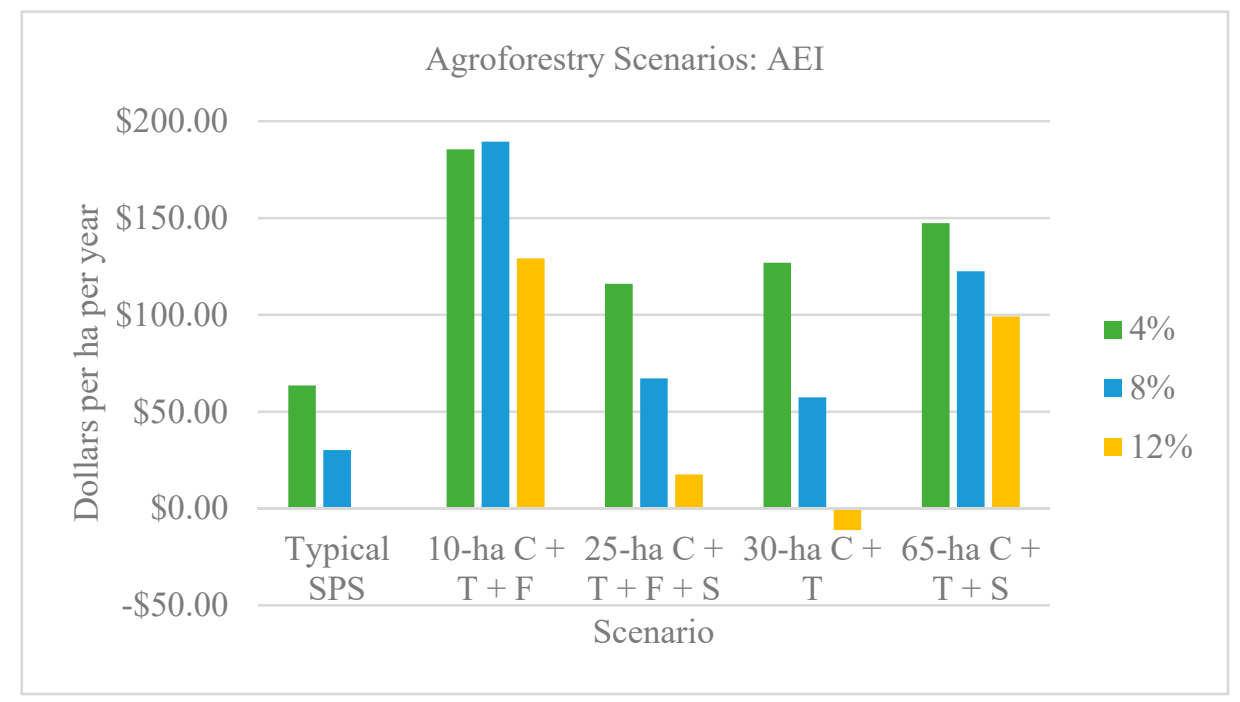

Figure 2. Annual equivalent income (AEI) of agroforestry systems.

Figure 3 displays the BCRs, a measure of the financial returns received per dollar spent in an investment, of all systems analyzed in the study. Tree plantations offered profitable returns per dollar invested at the lowest discount rate, as observed in its BCR, 1.27. At $8 \%$ and $12 \%$, the BCR of forest monocultures was less than 1 , signifying a loss per dollar invested $(0.87,0.61)$, due to the rapid diminution of future values. Dual-purpose cattle-forage regimes were cost-intensive and generated approximately USD 1.11 per dollar invested at the lowest discount rate (BCR: $4 \%=1.11,8 \%=1.07$, $12 \%=1.02$ ). The returns per dollar invested in silvopastures included a combination of costs and benefits from each industry (BCR: $4 \%=1.16,8 \%=1.08,12 \%=1.00$ ). The returns per dollar invested in the 10-ha actual farm increased as the discount rate increased (BCR: $4 \%=1.62,8 \%=1.66,12 \%=1.71$ ). The 25-ha mixed-use farm required high management intensity and generated just over a dollar per dollar spent at $12 \%(B C R: 4 \%=1.27,8 \%=1.15,12 \%=1.04)$. The 30-ha silvopasture with an absentee landowner lost USD 0.02 per dollar invested at the highest discount rate (BCR: $4 \%=1.24,8 \%=1.11$, $12 \%=0.98)$. The 65 -ha silvopastoral system with a restaurant and timber sale on site generated over USD 2 per dollar invested at all discount rates (BCR: $4 \%=2.54,8 \%=2.33,12 \%=2.12$ ).

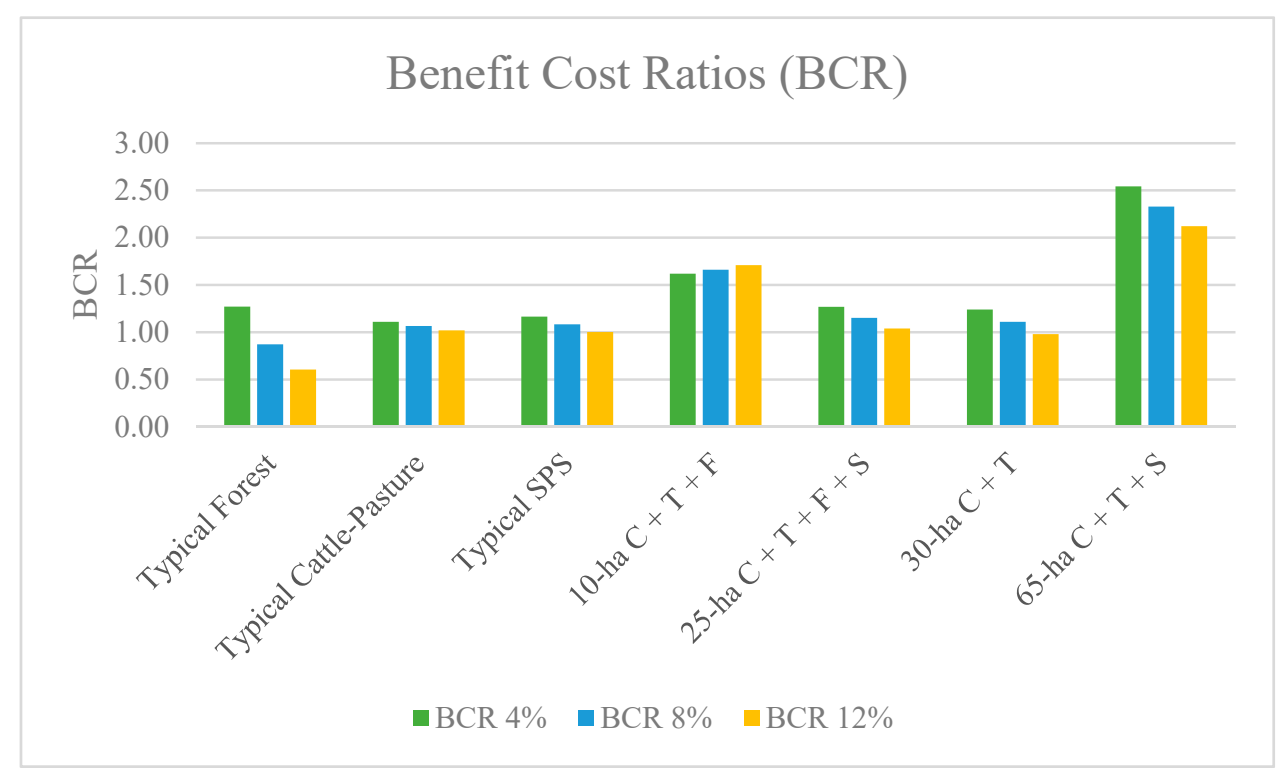

Figure 3. Benefit-cost ratios (BCR) for the evaluated scenarios. 
The production systems analyzed required varying degrees of establishment intensity (Table 4). Of the three model scenarios, pure forest investments demanded the least in establishment inputs (USD 1130.50/ha). However, due to the longer turn-around time before generating a positive net income, forest monocultures also were associated with the longest payback period, in non-present value terms (8 years). While traditional cattle-pasture regimes required higher cost inputs for establishment (USD 1197.53/ha), they produced positive net returns sooner than planted forests (3 years). Establishing the typical cattle-pasture operation and the typical SPS required similar costs, differentiated only by the inputs needed to plant trees in the SPS. Cattle purchases were not included in this metric as they occur after pasture and trees are established. Establishment costs of hypothetical and actual silvopastures ranged from USD 623.99 to USD 1183.10 per ha and required 1 to 5 years to pay back, in non-present value terms.

Table 4. Establishment costs (not discounted) and payback periods for all scenarios.

\begin{tabular}{ccc}
\hline Scenario & Establishment Cost (USD/ha) & Payback Period (Years) \\
\hline Typical Forest & USD 1130.50 & 8 \\
Typical Cattle + Pasture & USD 1197.53 & 3 \\
Typical SPS & USD 1203.35 & 4 \\
10-Ha C + T + F & USD 915.56 & 1 \\
25-Ha C + T + F + S & USD 1183.10 & 1 \\
30-Ha C + T & USD 1082.35 & 5 \\
65-Ha C + T + S & USD 623.99 & 5 \\
\hline
\end{tabular}

Cost-share payments at various rates pay landowners part of the establishment costs necessary to develop a tree plantation or other conservation practices. These are common in the United States now and were in Latin America in the past, and increase the net present value exactly by the amount paid in year 0 , as well shorten the payback period needed to generate positive net earnings. An assumed one-time $50 \%$ cost-share payment during the first years of USD 87.61 per hectare increased the LEV of the typical silvopasture scenario to USD 90.29 per hectare at a $12 \%$ discount rate. The cost-share payments in the initial years increased the NPV or LEV by the amount of the payment, ceteris paribus. Payments for environmental services (PES), such as carbon sequestration and water quality protection, can help increase the returns of agroforestry systems and provide landowners an equal choice between land uses. Mixed systems, both hypothetical and actual, experienced higher returns than the monoculture alternatives at discount rates of $4 \%$ and $8 \%$. At $12 \%$, typical silvopastures earned USD 71.19 per ha less in present value terms than conventional cattle-forage systems and required an annuity of USD 12.60 per ha for 10 years to breakeven.

Using a growth rate of $5 \mathrm{~m}^{3} /$ ha/year and an approximate biomass volume of $42.7 \%$ dry wood volume [18], we estimated the net carbon flow of each tree-based land-use system. The baseline comparison to show additional carbon storage was traditional cattle-pasture systems. The derived aboveground carbon accumulation rate for pure planted forests in Amazonas was 2.56 tons/ha/year (9.4 metric tons $\mathrm{CO}_{2} \mathrm{e} / \mathrm{ha} /$ year). Typical silvopastures with $15-20 \%$ trees store $0.38-0.51$ tons of carbon/ha/year (1.39-1.88 metric tons $\mathrm{CO}_{2} \mathrm{e} /$ ha/year). In a 25-year rotation, landowners may sequester 34.75-47 metric tons $\mathrm{CO}_{2} \mathrm{e} / \mathrm{ha}$.

\section{Discussion}

In Amazonas, Peru, we modeled three representative crop, forest, and silvopasture systems (SPS) based on previous farm owner surveys, interviewed four landowners or land managers as empirical case studies, and estimated their financial returns using capital budgeting techniques. The case study systems included dual-purpose dairy cattle with some forests, and often with on-farm retail stands. The span of systems analyzed in this study provided a mix of inputs and returns. The increased profitability of complex agroforestry scenarios to private landowners may have resulted from the reduced management costs, compared to monoculture systems, and the resulting increased 
system productivity through complementary biophysical characteristics. Some owners also made and sold cheese, yogurt, and jams at their farms-adding value and a handy outlet for their raw products. The "typical" model systems identified by the co-authors and based on past surveys [28-31] were moderately profitable. The actual operations visited demonstrated that with increased system complexity, and some home stores with added value for the products, returns could increase as well, at least by the best landowners. With a limited sample of farms, more replications are required to better determine impacts from returns to scale and added value products.

Planted forests appeared to have the most opportunity to be cost-effective for landowners with limited capital, generating the highest ratio of returns in proportion to total expenditures, as seen through the system's BCR. Low-input land-use methods may be appealing to those interested in systems with moderate profitability and limited costs. However, tree plantations earned relatively low returns at all discount rates, compared to cattle or mixed-use systems, required longer payback periods to cover establishment costs, and had less certain and established markets. PES incentives such as cost-share payments encourage landowners to invest in land-use systems by reducing initial costs and increasing income sooner. The calculated cost-share payment necessary to breakeven with conventional cattle systems was less than the U.S. national average rental payment, USD 133.86 per ha, offered in the Conservation Reserve Program (CRP) [37]. With PES, the payment amount needs to be at least the difference in returns between incorporating forest cover through silvopasture and the conventional more profitable use to provide an equal choice to landowners.

The returns for the 10-ha dairy-fruit SPS were the greatest in our small sample in Amazonas. However, we did not include on-farm home labor of the primary landowner as a cost, whether active onsite or absentee. The profits essentially represented the landowner income, so their returns per hectare were high, but the total area was relatively small. Nevertheless, only the 30-ha and the 65-ha farms earned a greater annual income than the average annual income of farmers in the region. Generally, systems utilized family labor when possible. As system size increases, the need for additional labor increases. The 25-ha and 65-ha systems, including a store and restaurant, respectively, did not earn as high of returns as the 10-ha and 30-ha systems at the lowest discount rate. The 10-ha and 65-ha systems used mostly family labor, while the other two systems employed more outside laborers. Nonetheless, salaries were deducted from the returns to represent the opportunity cost of all necessary laborers, both familial and hired, outside of the primary landowner in the analysis.

The varying results suggested that different mixes of production systems along with management intensities play a role in determining landowner profitability. Both the 10-ha and 65-ha regimes were associated with relatively low-intensity management, in terms of inputs, including but not limited to their self-sufficiency in labor. However, the 10-ha farm, both smaller in size and less profitable per dollar invested, generated higher net returns in present value terms than the 65-ha system at all discount rates. This smaller farm along with the larger 25 -ha farm sold fruit and home-made cheese, which increased returns. This corroborated that larger investments with more value-added can increase discounted present values, but they required more technical and managerial time and skill. The relationship between the resource variables and the capital budgeting results requires more analysis to determine their marginal impacts on returns per unit of land.

Small landowners often have limited capital and need frequent streams of income, which limits long-term investments. In addition, all systems other than the two largest actual farms earned less than the average annual income for farm laborers. Likewise, it took more time to cover establishment costs in forest systems when compared to cattle and agroforestry systems. Tremblay et al. [38] found fruit-bearing agroforests generated positive profits after 7 years, reinforcing this study's estimates. The difference in returns as well as the turn-around time for landowners to generate positive profits represent challenges that governmental policies can alleviate in order to encourage investment in expanding forest cover in agricultural systems [39].

For example, PES such as offsets for forest carbon storage have the potential to increase and diversify returns as well as make less profitable land uses more attractive. The average price of 
offsets for carbon stored in forests in 2016 was USD 5.10 per ton $\mathrm{CO}_{2}$ e [40]. This means that with favorable carbon markets, silvopasture practitioners in Amazonas may be able to earn USD 177-USD 240/ha per 25-year rotation. Governmental intervention may be necessary through PES programs such as payments for carbon sequestration to make less profitable land-use systems competitive with conventional cattle-forage systems [39]. This would be consistent with the ambitions announced by the Peruvian authorities, in their plans to reduce net carbon emissions in the country. PES may also supplement annual income to landowners to make their profits comparable to income earned by workers in the farming industry, thus, ensuring an adequate income to landowners of rural lands.

Moreover, since the cost of land purchase was not considered in the analysis, we were able to compare LEV values with the average sale price of land to determine if the expected returns from the systems correlated with market prices for agricultural land. The average price of productive land for sale in Northern Peru, based on three lots on the market at the time of the study, was quite expensive, at USD 9618 per hectare [41]. At a 4\% discount rate, our typical systems based on prior farm surveys and expert opinion earned less, but the four actual systems met or exceeded that level. None of the LEVs were greater than USD 9618 at the $12 \%$ discount rate.

Accordingly, using discount rates of $4 \%, 8 \%$, and $12 \%$ provided a range of potential returns from land-use systems with various opportunity costs. Without the established literature and known landowner discount rates, using multiple discount rates allowed us to estimate returns with multiple preferences in mind. For instance, lower discount rates give more weight to long-term returns and less weight to short-term costs and benefits. Meanwhile, higher discount rates represent higher opportunity costs of alternative investments and/or involve riskier investments. For the scope of the study, we were able to see which land-use practices were more sensitive to high discount rates. Forests, which returned periodic, long-term revenues and required high establishment costs, experienced negative returns at $8 \%$ and $12 \%$ discount rates. Conventional cattle-forage systems in Amazonas appeared more resilient to high discount rates with relatively high returns at each discount rate. The lower-input case studies, the 10-ha and 65-ha regimes, maintained high returns at all discount rates, unlike the input-intensive 25-ha and 30-ha systems.

To our knowledge, no other projects have analyzed the economic returns of SPS compared to planted trees monocultures and traditional cattle grazing regimes in Amazonas, Peru. Our findings from Amazonas compare favorably with those of other global SPS research. In the Amazon lowlands of Ecuador, SPS featuring traditional and improved species of forage earned negative NPVs at $8 \%$, -USD 356.17 per hectare and -USD 206.58 per hectare, respectively, but higher returns than traditional cattle ranching [42]. Other studies also highlighted the potential of added value from fruit-tree-based systems. For example, Tremblay et al. [38] recognized the economic advantages of silvopasture as a sustainable alternative land-use for small-scale agriculture in the Tapajos region of the Brazilian Amazon. At a 10\% discount rate, the net present values of the agroforests returned USD 17,800 for the medium-sized orchard and USD 21,844 for the larger orchard. In addition, Hoch et al. [43] estimated positive NPVs at $3 \%$ and $12 \%$ discount rates for successful intercropping studies in Brazil, Bolivia, Peru, and Ecuador as part of a non-governmental agency's initiative.

Silvopasture systems are posited to provide significant risk reduction benefits because they produce at least two different commodities, which would have different, uncorrelated market price cycles given their different product life-cycle time spans [21]. In financial investment portfolio theory, any two or more uncorrelated investments will lead to larger overall investment returns. There is not much empirical literature on such financial risk benefits of silvopasture systems, and the complexity of finding historical returns and distributions and using them to estimate risk was beyond the scope of this study. We could have varied input costs and output prices for sensitivity or risk analyses, but given the many different factors of production and the lack of empirical cost distributions for any of our inputs, varying some arbitrary combination of these would not be supportable for this research.

Frey et al. [15] surveyed small-scale farmers in northeast Argentina, and found they believed that diversified cash flows, and thus, less risk of single commodity price fluctuations, were significant 
advantages of silvopasture. The mixed-use systems analyzed by Dube et al. $[19,20]$ in Chile and Brazil showed positive potential for benefits by risk reduction from multiple products and carbon storage benefits. Similar approaches could be facilitated in Peru with financial assistance. Comparable studies acknowledged establishment costs to adopt silvopasture as well as increased labor as barriers for landowners with limited income $[38,43,44]$. A trade-off exists between the benefits of diverse mutually compatible species and its increased demand of specialized labor [13]. However, they also recognized the potential of timber sales to cover upfront and additional management costs [44], in addition to increased social and conservation benefits that are not always financially captured from silvopastures [38,45].

\section{Conclusions}

We estimated the financial returns for silvopasture systems in Amazonas, Peru based on previous farm surveys and representative models and four selected case studies of successful SPS farms based on local contacts with the co-authors. Pure cattle-pasture systems had larger returns in the synthetic calculations, but for the four integrated case studies that had pasture, forests, and some processing or retail parts of the value chain, silvopasture systems all had the greatest returns. However, the markets for wood are local and informal, so prices and quantity purchased depend on farm labor and individual negotiations, not established timber markets.

We made the analyses using the best available market prices or the estimated market equivalent of factor costs and output prices. We did not estimate social welfare or shadow prices for factors of production or output. Per strict economics jargon, we performed a financial analysis using discounted cash flows and capital budgeting criteria. We have referred to the research as an economic analysis as well, using the terms interchangeably per common usage [32]. Purists suggest that comprehensive economic analyses should include all the social (e.g., shadow prices, social welfare, non-market values) estimates of goods and services, but we used the most common convention and term of an economic or financial analysis for market prices, as is applied almost universally.

The sampled landowners captured excellent economic returns through SPS systems and diverse farm product sales, but they were exceptional opinion and business leaders. Achieving similar success for silvopasture with smaller typical landowners will require more research into the best practices for limited income farmers, extension advice, and implementation of good farm management practices as well. The opportunity cost of alternative investments will determine whether diversifying land-use through agroforestry will increase landowner returns.

Government support through direct payments could increase the profitability of silvopastures in order to gain ecosystem service benefits such as carbon storage or improved water quality. Cost-share payments may make land uses that expand forest cover more desirable to landowners by reducing establishment costs. Cost-share payments also have the potential of shortening payback periods so limited income landowners can reach a net positive cash flow sooner. When cost-share payments are not enough to make silvopasture more profitable, other PES, such as carbon storage, may be employed to provide a stream of annual benefits over some time period, e.g., the first ten years when revenue is at its lowest. Payments to landowners for carbon sequestration represent a promising solution to the low profits of silvopasture regimes at high discount rates. However, with low carbon prices, the absence of mature markets, and competitive resource relationships, carbon payments may not be sufficient to make silvopasture competitive with conventional cattle-pasture systems. In these cases, multiple forms of aid may be necessary to encourage landowners to adopt land-uses such as agroforestry. Overall, mixed-use systems in Amazonas represent essential models of land-use regimes which can be altered and/or replicated to produce supportable livelihoods for landowners.

Author Contributions: Conceptualization, M.C. and F.C.; methodology, F.C. and R.R.; formal analysis, S.C.; interviews and investigation, S.C., F.C., D.P., H.V., W.B.; resources, F.C.; data curation, S.C., F.C., D.P., W.B. and H.V.; writing—original draft preparation, S.C.; writing-review and editing, S.C., F.C., M.C., D.P., W.B., R.R., H.V., and R.P.; supervision, F.C., R.A., R.P. and E.S.; funding acquisition, S.C., R.A. and F.C. All authors have read and agreed to the published version of the manuscript. 
Funding: The Southern Forest Resource Assessment Consortium (SOFAC) and the Bruce and Barbara Zobel Endowment for International Forestry Studies provided the funds for this study.

Acknowledgments: We would like to thank the landowners that graciously allowed us to visit and use their farms in this analysis and the Peruvian collaborators that provided their guidance and expertise. We appreciate the suggestions and comments from both our own and Land's reviewers and editors.

Conflicts of Interest: The authors declare no conflict of interest. The funders did not have any influence on the methods or results of the study.

\section{References}

1. Aynekulu, E.; Suber, M.; van Noordwijk, M.; Arango, J.; Roshetko, J.M.; Rosenstock, T.S. Carbon Storage Potential of Silvopastoral Systems of Colombia. Land 2020, 9, 309. [CrossRef]

2. Zomer, R.J.; Neufeldt, H.; Xu, J.; Ahrends, A.; Bossio, D.; Trabucco, A.; Wang, M. Global Tree Cover and Biomass Carbon on Agricultural Land: The Contribution of Agroforestry to Global and National Carbon Budgets. Scientific Reports, 6. 2016. Available online: http://search.proquest.com.prox.lib.ncsu.edu/docview/ 1817890421?pq-origsite $=$ summon (accessed on 9 January 2018).

3. Orefice, J.N.; Carroll, J. Silvopasture-It's not a Load of Manure: Differentiating Between Silvopasture and Wooded Livestock Paddocks in the Northeastern United States. J. For. 2017, $115,71$. Available online: http://search.proquest.com.prox.lib.ncsu.edu/docview/1863558982?pq-origsite=summon\& accountid=12725 (accessed on 7 January 2018). [CrossRef]

4. USDA National Agroforestry Center. Silvopasture: An Agroforestry Practice [PowerPoint Slides]. 2012. Available online: https://nac.unl.edu/practices/silvopasture.htm (accessed on 1 April 2017).

5. Cotta, J.N. Revisiting Bora fallow agroforestry in the Peruvian Amazon: Enriching ethnobotanical appraisals of non-timber products through household income quantification. Agroforest. Syst. 2017, 91, 17-36. Available online: https://ink-springer-com.prox.lib.ncsu.edu/article/10.1007\%2Fs10457-016-9892-4 (accessed on 30 March 2017). [CrossRef]

6. Lacerda, A.E.B.; Hanisch, A.L.; Nimmo, E.R. Leveraging Traditional Agroforestry Practices to Support Sustainable and Agrobiodiverse Landscapes in Southern Brazil. Land 2020, 9, 176. [CrossRef]

7. Chizmar, S.; Sills, E.; Cubbage, F.; Castillo, M.; Abt, R. A Comparative Economic Assessment of Silvopasture Systems in the Amazonas Region of Peru and in North Carolina. Master's Thesis, North Carolina State University, Raleigh, NC, USA, 2018. Available online: http://www.lib.ncsu.edu/resolver/1840.20/35059 (accessed on 5 May 2018).

8. Van Noordwijk, M.; Gitz, V.; Minang, P.A.; Dewi, S.; Leimona, B.; Duguma, L.; Pingault, N.; Meybeck, A. People-Centric Nature-Based Land Restoration through Agroforestry: A Typology. Land 2020, 9, 251. [CrossRef]

9. Ministry of Environment [MINAM]. Intended Nationally Determined Contribution from the Republic of Peru. 2015. Available online: http://www4.unfccc.int/ndcregistry/PublishedDocuments/Peru\%20First/ iNDC\%20Per\%C3\%BA\%20english.pdf (accessed on 18 May 2018).

10. Bonn Challenge. n.d. Commitments: Peru. Available online: http://www.bonnchallenge.org/content/peru (accessed on 1 May 2017).

11. Sistema Nacional de Evaluation Acreditacion y Certificacion de la Calidad Educativa [SINEACE]. Caracterización de la Región Amazonas. 2017. Available online: https://www.sineace.gob.pe/wp-content/ uploads/2017/08/PERFIL-AMAZONAS.pdf (accessed on 18 May 2018).

12. City Population. Amazonas. 2 October 2018. Available online: https://www.citypopulation.de/php/peruadmin.php?adm1id=01 (accessed on 1 February 2018).

13. Loker, W.M. Where's the beef? Incorporating Cattle into Sustainable Agroforestry Systems in the Amazon Basin. Agroforest. Syst. 1994, 25, 227-241. Available online: https://ink.springer.com/article/10.1007/ BF00707462 (accessed on 21 May 2018). [CrossRef]

14. Bussoni, A.; Juan, C.; Fernandez, E.; Boscana, M.; Cubbage, F.; Bentancur, O. Integrated beef and wood production in Uruguay: Potential and limitations. Agroforest. Syst. 2015, 89, 1107-1118. Available online: https://link-springer-com.prox.lib.ncsu.edu/article/10.1007\%2Fs10457-015-9839-1 (accessed on 4 May 2017). [CrossRef] 
15. Frey, G.E.; Fassola, H.E.; Pachas, A.N.A.; Colcombet, L.; Lacorte, S.M.; Pérez, O.; Renkow, M.; Warren, S.T.; Cubbage, F.W. Perceptions of silvopasture systems among adopters in northeast Argentina. Agric. Syst. 2012, 105, 21-32. Available online: https://www-sciencedirect-com.prox.lib.ncsu.edu/science/article/pii/S0308521\$ times $\$ 11001272$ (accessed on 1 February 2018). [CrossRef]

16. Walthall, C.L.; Hatfield, J.; Backlund, P.; Lengnick, L.; Marshall, E.; Walsh, M.; Adkins, S.; Aillery, M.; Ainsworth, E.A.; Ammann, C.; et al. Climate Change and Agriculture in the United States: Effects and Adaptation. In USDA Technical Bulletin 1935; USDA: Washington, DC, USA, 2012; pp. 1-193. Available online: https://www.usda.gov/oce/climate_change/effects_2012/CC\%20and\%20Agriculture\%20Report\% 20(02-04-2013)b.pdf (accessed on 1 May 2017).

17. Nair, P.K.R. Methodological challenges in estimating carbon sequestration potential of agroforestry systems. In Carbon Sequestration Potential of Agroforestry Systems: Opportunities and Challenges; Kumar, B.M., Nair, P.K.R., Eds.; Springer: Dordrecht, The Netherlands, 2011; pp. 3-16. Available online: https://link-springer-com.prox. lib.ncsu.edu/chapter/10.1007\%2F978-94-007-1630-8_1 (accessed on 8 April 2017).

18. Oliva, M.; Mirano, L.C.; Leiva, S.; Collazos, R.; Salas, R.; Vásquez, H.V.; Quintana, J.L.M. Reserva de carbono en un sistema silvopastoril compuesto de Pinus patula y herbáceas nativas. Sci. Agropecu. 2017, 8, 149-157. [CrossRef]

19. Dube, F.; Thevathasan, N.V.; Zagal, E.; Gordon, A.M.; Stolpe, N.B.; Espinosa, M. Carbon sequestration potential of silvopastoral and other land use systems in the Chilean Patagonia. In Carbon Sequestration Potential of Agroforestry Systems: Opportunities and Challenges; Kumar, B.M., Nair, P.K.R., Eds.; Springer: Dordrecht, The Netherlands, 2011; pp. 101-127. Available online: https://link-springer-com.prox.lib.ncsu. edu/chapter/10.1007\%2F978-94-007-1630-8_6 (accessed on 15 June 2017).

20. Dube, F.; Couto, L.; Silva, M.L.; Leite, H.G.; Garcia, R.; Araujo, G.A. A simulation model for evaluating technical and economic aspects of an industrial eucalyptus-based agroforestry system in Minas Gerais, Brazil. Agroforest. Syst. 2002, 55, 73-80. Available online: https://link-springer-com.prox.lib.ncsu.edu/article/10. 1023\%2FA\%3A1020240107370 (accessed on 15 June 2017). [CrossRef]

21. Cubbage, F.W.; Balmelli, G.; Bussoni, A.; Noellemeyer, E.; Pachas, A.N.; Fassola, H.; Colcombet, L.; Rossner, B.; Frey, G.; Dube, F.; et al. Comparing silvopastoral systems and prospects in eight regions of the world. Agroforest. Syst. 2012, 86, 303-314. [CrossRef]

22. Montagnini, F.; Nair, P.K.R. Carbon sequestration: An underexploited environmental benefit of agroforestry systems. Agroforest. Syst. 2004, 61, 281-295. Available online: https://link-springer-com.prox.lib.ncsu.edu/ content/pdf/10.1023\%2FB\%3AAGFO.0000029005.92691.79.pdf (accessed on 1 February 2018).

23. Orefice, J.N.; Smith, R.G.; Carroll, J.; Asbjornsen, H.; Howard, T. Forage productivity and profitability in newly-established open pasture, silvopasture, and thinned forest production systems. Agroforest. Syst. 2019, 93, 51-65. [CrossRef]

24. Bruck, S.R.; Bishaw, B.; Cushing, T.L.; Cubbage, F.W. Modeling the financial potential of silvopasture agroforestry in eastern North Carolina and northeastern Oregon. J. For. 2019, 177, 13-20. [CrossRef]

25. Pent, G.J.; Fike, J.H. Winter Stockpiled Forages, Honeylocust Pods, and Lamb Performance in Hardwood Silvopastures \& Sheep Performance and Behavior in Silvopasture Systems. In Proceedings of the Agroforestry for a Vibrant Future: Connecting People, Creating Livelihoods, Sustaining Places 15th NAAC on the Campus of Virginia Tech in Blacksburg, Blackburg, VA, USA, 27-29 June 2017.

26. Mercer, D.E.; Frey, G.E.; Cubbage, F.W. Economics of agroforestry. In Handbook of Forest Economics; Kant, S., Alavalapati, J.R.R., Eds.; Routledge: New York, NY, USA, 2014; pp. 188-209. Available online: https://www.srs.fs.usda.gov/pubs/ja/2014/ja_2014_mercer_001.pdf (accessed on 9 October 2017).

27. Holdridge, L.R. Life Zone Ecology; Tropical Science Center: San Jose, CA, USA, 1967.

28. Gómez, C.A. Sistemas Silvopastoriles: Investigación e Innovación en el caso de Amazonas y San Martín. In I Curso Internacional Ganadería y Agroecosistemas Tropicales Sostenibles Para Enfrentar el Cambio Climático: Sistemas Silvopastoriles; Print: Pucallpa, Peru, 2017.

29. Pizarro, D.; Vasquez, H.; Bernal, W.; Fuentes, E.; Alegre, J.; Castillo, M.S.; Gomez, C. Assessment of silvopasture systems in the northern Peruvian Amazon. Agroforest. Syst. 2020, 94, 173-183. [CrossRef]

30. Alegre, J.C.; Sánchez, Y.; Pizarro, D.M.; Gómez, C.A. Manejo de los Suelos con Sistemas Silvopastoriles en las Regiones de Amazonas y San Martín; Print: Lima, Peru, 2019.

31. Echevarría, M.G.; Pizarro, D.M.; Gómez, C.A. Alimentación de Ganadería en Sistemas Silvopastoriles de la Amazonia Peruana; Print: Lima, Peru, 2019. 
32. Cubbage, F.W.; Davis, R.R.; Frey, G.E.; Behr, D.C.; Sills, E.O. Financial and economic evaluation guidelines for international forestry projects. In Tropical Forestry Handbook; Pancel, L., Kohl, M., Eds.; Springer Publishing: Berlin, Germany, 2016. [CrossRef]

33. Sharrow, H. Natural Resource Economics: Considering the Time Element of Investments. 2008. Available online: http://www.doctorrange.com/PDF/TimeinNRInvest.pdf (accessed on 1 April 2017).

34. Bullard, S.H.; Straka, T.J. Basic Concepts in Forest Valuation and Investment Analysis, 3rd ed.; Faculty Publications: Nacogdoches, TX, USA, 2011; p. 460. Available online: http://scholarworks.sfasu.edu/forestry/460 (accessed on 19 September 2020).

35. Porro, R.; Miller, R.P.; Tito, M.R.; Donovan, J.A.; Vivan, J.L.; Trancoso, R.; Van Kanten, R.F.; Grijalva, J.E.; Ramirez, B.L.; Gonçalves, A.L. Agroforestry in the Amazon Region: A pathway for balancing conservation and development. In Agroforestry-The Future of Global Land Use; Nair, P.K.R., Garrity, D., Eds.; Springer: Dordrecht, The Netherlands, 2012; pp. 391-427. Available online: https://link-springer-com.prox.lib.ncsu. edu/book/10.1007\%2F978-94-007-4676-3 (accessed on 1 April 2017).

36. Alegre, J.C. Sistema agroforestal multiestrato. Recuperación de suelos degradados en la amazonía. Rev. Leisa 2015, 31, 28-30. Available online: http://www.leisa-al.org/web/index.php/volumen-31-numero-1/ 1091-sistema-agroforestal-multiestrato-recuperacion-de-suelos-degradados-en-la-amazonia (accessed on 1 April 2017).

37. USDA Farm Service Agency. The Conservation Reserve Program: 49th Signup Results. USDA. 2016. Available online: https://www.fsa.usda.gov/Assets/USDA-FSA-Public/usdafiles/Conservation/PDF/SU49Book_State_ final1.pdf (accessed on 1 April 2017).

38. Tremblay, S.; Lucotte, M.; Reveret, J.; Davidson, R.; Mertens, F.; Sousas Passos, C.J.; Romaña, C.A. Agroforestry systems as a profitable alternative to slash and burn practices in small-scale agriculture of the Brazilian Amazon. Agroforest. Syst. 2015, 89, 193-204. [CrossRef]

39. Vosti, S.A.; Braz, E.M.; Carpentier, C.L.; d'Oliveira, M.V.; Witcover, J. Rights to forest products, deforestation and smallholder income: Evidence from the western Brazilian Amazon. World Dev. 2003, 31, 1889-1901. [CrossRef]

40. Hamrick, K.; Gallant, M. Unlocking Potential State of the Voluntary Carbon Markets 2017. Forest Trends' Ecosystem Marketplace. 2017. Available online: https://www.cbd.int/financial/2017docs/carbonmarket2017. pdf (accessed on 4 January 2018).

41. Realigro Real Estate. Peru. 2015. Available online: https://peru.realigro.com/for-sale/farmland/\#annunci (accessed on 9 October 2017).

42. Ramírez, A.; Seré, C.; Uquillas, J. An economic analysis of improved agroforestry practices in the Amazon lowlands of Ecuador. Agroforest. Syst. 1992, 17, 65-86. Available online: https://link.springer.com/article/10. 1007/BF00122928 (accessed on 1 April 2017).

43. Hoch, L.; Pokorny, B.; de Jong, W. Financial attractiveness of smallholder tree plantations in the Amazon: Bridging external expectations and local realities. Agroforest. Syst. 2012, 84, 361-375. [CrossRef]

44. Adams, M.L. Pasture extensification in the Southern Ecuadorian Andes: Appraisal and recommendations. J. Sustain. For. 2009, 28. [CrossRef]

45. McDermott, M.E.; Rodewald, A.D. Conservation value of silvopastures to Neotropical migrants in Andean forest flocks. Biol. Conserv. 2014, 175. [CrossRef]

(C) 2020 by the authors. Licensee MDPI, Basel, Switzerland. This article is an open access article distributed under the terms and conditions of the Creative Commons Attribution (CC BY) license (http://creativecommons.org/licenses/by/4.0/). 